\title{
Polysaccharides and Glycoproteins in the Rice Endosperm Cell Wall
}

\author{
Naoto SHibuYa and Tetsuya IwASAKI \\ National Food Research Institute, Ministry of Agriculture and Forestry, \\ 1-4-12 Shiohama, Koto-ku, Tokyo 135 \\ Received June 1, 1978
}

\begin{abstract}
Endosperm cell walls were isolated from rice grains and their chemical composition was analyzed. The cell walls were composed of cellulose microfibrils and matrix phase which consisted of hemicellulose and pectic substances. Hemicellulose mainly comprised arabinoxylan, accompanied by a small amount of glucose-containing polysaccharide. Pectic substances contained polygalacturonides, some of which had side chains containing neutral sugars such as galactose and arabinose. Amino acid analysis of these fractions suggested that hydroxyproline-containing glycoproteins were contained in these cell walls and firmly bound to cellulose microfibrils.
\end{abstract}

Endosperm of cereal grains, such as rice, wheat and barley, is composed of numerous cells which contain starch, protein and other reserve materials. The cell walls of these endosperm cells are disintegrated during various stages of processing in the food industry including milling, brewing and cooking. It has been reported that the properties of these walls affect the milling quality of wheat, ${ }^{1 \sim 2 \text { ? }}$ physical properties of some cereal products, ${ }^{3 \sim 5)}$ and sometimes caused troubles in "Sake" brewing. ${ }^{6}$

Thus studies on the structure and chemical constitution of these cell walls seem to be meaningful to the improvement of these processes. Such studies will also provide useful information for better understanding of the germination processes of these grains, in which some modification of the cell walls may occur. $^{7,8}$

However, few reports have dealt with the isolation and characterization of the endosperm cell wall itself, although many workers have studied on the soluble and insoluble polysaccharides of these grains, ${ }^{9 \sim 13}$ ) some of which might belong to these cell walls.

Recently, Mares et al. $^{14)}$ and Fincher ${ }^{15)}$ isolated endosperm cell walls from wheat and barley, respectively, and examined their chemical and morphological aspects. Sugano et al. ${ }^{16)}$ also isolated endosperm cell walls from rice and examined the aggregation of them with brewer's yeasts, but they reported no detailed chemical composition of the cell walls.

In this paper, we describe the macromolecular composition of the endosperm cell walls of rice and some properties of these components.

\section{MATERIALS AND METHODS}

Materials. Rice (Oriza sativa, cultivars Norin 29) was harvested in Ibaragi prefecture, Japan. Alpha amylase of Bacillus subtilis (BLA, $3 \times$ crystallized), glucoamylase of Rhizopus niveus (fine grade) and protease of Aspergillus melleus ( $1 \times$ crystallized) were all purchased from Seikagaku Kogyo Co., Tokyo.

Isolation of endosperm cell walls. Brown rice was milled with a testing mill (Satake Engineering Co., Tokyo; milling yield, $90 \%$ on a brown rice basis) and then ground to pass through a 50-mesh sieve. The milled rice flour ( $341 \mathrm{~g}$, in dry weight) was extracted succesively with cold water and with $1: 1$ ethanolether. The defatted flour was suspended in a tenfold volume of distilled water which contained BLA (70 units $/ \mathrm{ml}$ ) and $0.002 \mathrm{M}$ of calcium chloride. After its $\mathrm{pH}$ was adjusted to 6.0 with sodium hydroxide, the suspension was heated to $93^{\circ} \mathrm{C}$ and kept for $30 \mathrm{~min}$. The supernatant of this reaction mixture was further digested with glucoamylase $\left(5.0\right.$ units $/ \mathrm{ml}, \mathrm{pH} 5.0,50^{\circ} \mathrm{C}$, $5 \mathrm{hr}$ ) to convert the dextrin into glucose, then dialyzed against distilled water and lyophylized. The polysaccharide fraction so obtained was designated as WS (121 $\mathrm{mg}$ in lyophylized powder).

The insoluble residue of the BLA digest was sus- 
pended in $0.05 \mathrm{M}$ phosphate buffer ( $\mathrm{pH} 7.6$ ), which contained protease ( 950 units $/ \mathrm{ml}$ ), and incubated at $40^{\circ} \mathrm{C}$ for $4 \mathrm{hr}$. The endosperm cell walls were obtained by passing the reaction mixture through a glass beadbedded filter in accordance with the method of Kivilaan. ${ }^{17}$ The protease digestion and successive filtration were repeated untill the cell wall fraction was found homogeneous in microscopic observation (605 $\mathrm{mg}$ in lyophylized powder).

Fractionation of the endosperm cell walls and their fractions. The endosperm cell walls $(200 \mathrm{mg})$ were extracted with $0.25 \%$ ammonium oxalate solution at $90^{\circ} \mathrm{C}$ for $24 \mathrm{hr}$. The extract was dialyzed and lyophylized to give a pectin fraction $(14.6 \mathrm{mg})$. The insoluble residue was further extracted with $4 \mathrm{~N}$ potassium hydroxide at room temperature for $24 \mathrm{hr}$ under a nitrogen gas stream. The extract was also dialyzed and lyophylized to give a hemicellulose fraction (64.1 $\mathrm{mg}$ ). The residue of the alkaline extraction was washed thoroughly with distilled water and lyophylized to give an $\alpha$-cellulose fraction $(72.6 \mathrm{mg})$.

The pectin and hemicellulose were further fractionated by column chromatography on DEAE-cellulose and gel filtration on Sephadex G-50 or Sepharose 4B.

Sugar analysis. Total carbohydrate was determined by the phenol-sulfuric acid method. ${ }^{18)}$ Uronic acid content of each polysaccharide was determined by the carbazole method. ${ }^{18)}$

Polysaccharides except $\alpha$-cellulose were hydrolyzed with $1 \mathrm{~N}$ sulfuric acid for $12 \mathrm{hr}$ at $100^{\circ} \mathrm{C}$. $\alpha$-Cellulose was hydrolyzed by the method of Saeman et al. ${ }^{20)}$ The hydrolyzate was applied to a small column $(1 \times 6 \mathrm{~cm})$ of Amberlite CG-400 to neutralize the acid and also to adsorb uronic acids on it. Neutral sugars were eluted from the column with distilled water, and then uronic acids were eluted with $4 \mathrm{~N}$ acetic acid. Neutral sugars were converted into corresponding alditol acetates and analyzed by gas chromatography. ${ }^{21)}$ Paper chromatography of uronic acids was performed on Toyo No. 50 filter paper with the solvent systems, (a) ethyl acetate: pyridine: acetic acid: water $(5: 5: 1: 3)$ and (b) ethyl acetate: acetic aced: water $(9: 2: 2)$. Uronic acids were also converted into methyl glycosides by heating them with $3 \%$ methanolic hydrogen chloride at $100^{\circ} \mathrm{C}$ for $12 \mathrm{hr}$. The methyl glycosides so obtained were trimethylsilylated ${ }^{22}$ and analyzed by gas chromatography on a column of OV-17.

Amino acid analysis. Amino acid analysis was performed with a Hitachi model KLA-3B automatic amino acid analyzer. The endosperm cell walls or $\alpha$-cellulose were directly hydrolyzed with $6 \mathrm{~N}$ hydrochloric acid at $110^{\circ} \mathrm{C}$ for $24 \mathrm{hr}$ in a sealed glass tube. After removal of hydrochloric acid, the hydrolyzate was dis- solved in the initial buffer and applied to the instrument. Determination of cystine, cysteine and tryptophan was omitted.

Determination of protein content. Protein contents of the endosperm cell walls and $\alpha$-cellulose were determined by the micro Kjeldahl method (protein, $\mathrm{N} \times$ 5.95), and those of the soluble polysaccharide fractions by the method of Lowry et al.2s)

Scanning electron microscopy of the endosperm cell walls. Microscopic observation was carried out with a Hitachi model MSM-2 scanning electron microscope. Lyophylized cell walls were mounted on a metal stub and coated with carbon and gold.

\section{RESULTS}

\section{Homogeneity of the isolated cell wall prepa- ration}

Figure 1 shows the scanning electron micrographs of the rice endosperm cell wall sample, which was prepared as described above. No contamination with starch granules or protein bodies was observed. Small, regular shaped particles were observed on the surface of the isolated cell walls (Fig. 1). Mares et al..$^{14)}$ and Fincher ${ }^{15}$ ) also reported the presence of similar particles on the outer surface of the endosperm cell walls of wheat and barley, respectively, but the physiological role of these particles is not yet clarified.

\section{Sugar compositions of pectin, hemicellulose, $\alpha$ - cellulose and WS fractions}

Table I shows the sugar composition of each fraction, which was obtained by the fractional extraction of the endosperm cell walls, together with the sugar composition of WS.

Hemicellulose gave mainly arabinose and xylose upon acid hydrolysis, indicating that the main component of this fraction was an arabinoxylan. Pectin showed a high uronic acid content (over 50\%) and seemed to contain polyuronides such as pectic acid. $\alpha$-Cellulose, having an over $95 \%$ glucose content, seemed to be composed of cellulose microfibrils. WS gave galactose, mannose, arabinose, glucose 


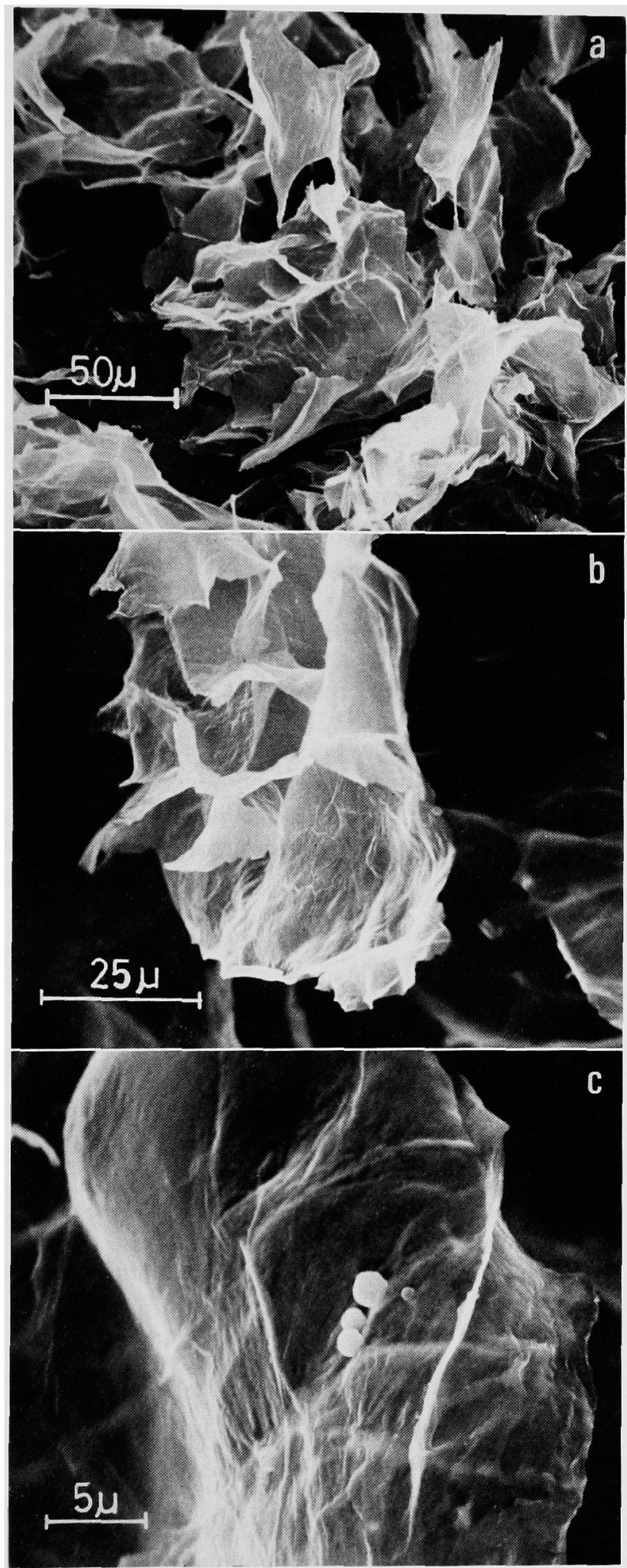


Table I. Sugar Compositions of Hemicellulose, Pectin, $\alpha$-Cellulose AND WS

\begin{tabular}{lcccr}
\hline \multirow{2}{*}{ Sugar } & \multicolumn{4}{c}{ Composition $(\%, w / w)$} \\
\cline { 2 - 5 } & $\begin{array}{c}\text { Hemicel- } \\
\text { lulose }\end{array}$ & Pectin & $\alpha$-Cellulose & WS \\
\hline Rham & 1.5 & 4.1 & - & 4.2 \\
Fuc & 0.5 & 1.1 & - & 3.9 \\
Ara & 31.5 & 13.7 & 2.8 & 12.6 \\
Xyl & 44.4 & 12.3 & 1.9 & 8.5 \\
Man & - & 4.3 & 0.3 & 19.8 \\
Gal & 0.7 & 7.8 & - & 23.2 \\
Glu & 8.8 & 1.5 & 95.0 & 12.6 \\
Uronic acid & 12.5 & 55.1 & - & 15.2 \\
\hline
\end{tabular}

a. Estimated in terms of galacturonic acid.

and xylose upon acid hydrolysis, suggesting that this fraction was a complicated mixture of several types of polysaccharides.

Fractionation of the crude hemicellulose by DEAE-cellulose column chromatography

Figure 2 shows the elution profile of the hemicellulose of rice endosperm cell walls on DEAE-cellulose (borate form). Table II shows the sugar composition of each fraction obtained by the chromatography.

Table II. Sugar Compositions of Hemicellulose Fractions

\begin{tabular}{|c|c|c|c|}
\hline \multirow{2}{*}{ Sugar } & \multicolumn{3}{|c|}{ Composition $(\%, w / w)$} \\
\hline & $\mathrm{H}-1$ & $\mathrm{H}-2$ & $\mathrm{H}-3$ \\
\hline Rham & 0.1 & 0.8 & 0.7 \\
\hline Fuc & - & 0.3 & 0.3 \\
\hline Ara & 44.9 & 34.8 & 21.3 \\
\hline $\mathrm{Xyl}$ & 50.6 & 45.8 & 32.4 \\
\hline Man & 0.3 & 0.4 & - \\
\hline Gal & 2.3 & 2.0 & 4.0 \\
\hline Glu & 1.8 & 3.1 & 27.8 \\
\hline Uronic acid ${ }^{a}$ & - & 12.9 & 13.5 \\
\hline
\end{tabular}

a Estimated in terms of galacturonic acid.

H-1, which was not adsorbed on this column, was an arabinoxylan having a high arabinose: xylose ratio of 0.89 . This fraction contained almost no uronic acid as its component sugar. On the other hand, $\mathrm{H}-2$, which was eluted from the column by increasing the concentration of the buffer, contained a considerable amount of uronic acids, though they also seemed to be an arabinoxylan (arabinose: xylose ratio, 0.76 ).

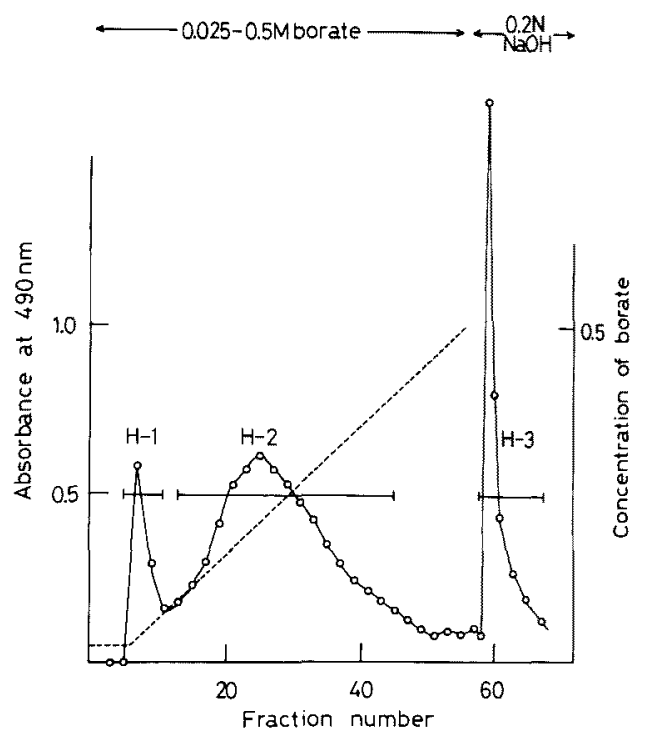

FrG. 2. DEAE-cellulose Column Chromatography of Hemicellulose.

Hemicellulose of the rice endosperm cell walls $(25 \mathrm{mg}$ in $5 \mathrm{ml}$ of $0.025 \mathrm{M}$ sodium borate, $\mathrm{pH}$ 9.2) was applied to a column of DEAE-cellulose $(1.5 \times 40 \mathrm{~cm})$, which had been equilibrated with the same buffer. The column was eluted with a linear gradient of the borate buffer from 0.025 to $0.5 \mathrm{M}(500 \mathrm{ml})$, and then with $0.2 \mathrm{~N} \mathrm{NaOH}$. The eluate was collected in $10 \mathrm{ml}$ fractions and analyzed for total carbohydrate. -.-.-., buffer concentration; $\mathrm{O}-\mathrm{O}$, total carbohydrate.

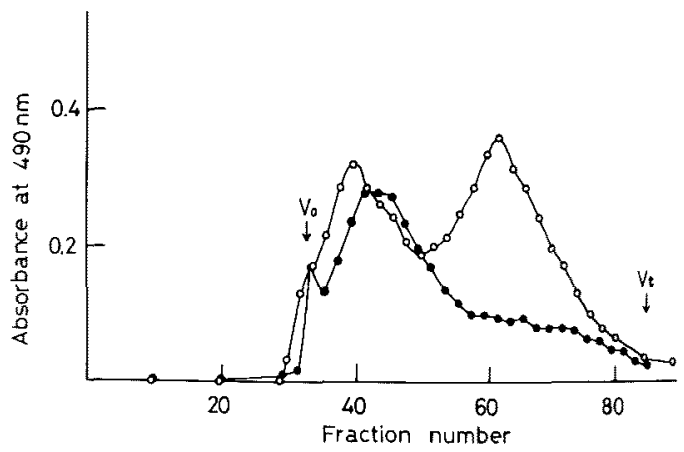

Frg. 3. Gel Filtration of H-2 and H-3 on Sepharose $4 \mathrm{~B}$.

H-2 or H-3 (3 $5 \mathrm{mg}$ each in $5 \mathrm{ml}$ of $0.05 \mathrm{M}$ phosphate buffer, $\mathrm{pH} 7.8$ ) was applied to a column of Sepharose 4B $(2.5 \times 90 \mathrm{~cm})$, which had been equilibrated with the same buffer. The eluate was collected in $5 \mathrm{ml}$ fractions and analyzed for total carbohydrate. $\mathrm{O}-\mathrm{O}$, $\mathrm{H}-2$;

H-3, which was strongly retained by this column and eluted with a sodium hydroxide 
solution, gave a considerable amount of glucose in addition to arabinose and xylose upon acid hydrolysis. H-3 reacted with iodine-potassium iodide reagent to manifest a green to blue color like starch, but the color was unstable and easily diminished as the solution was diluted. Moreover, H-3 could not be further degraded by alpha- or glucoamylase, suggesting that it was not a starch remnant.

Figure 3 shows the gel filtration patterns of $\mathrm{H}-2$ and $\mathrm{H}-3$ on Sepharose 4B. Both $\mathrm{H}-2$ and $\mathrm{H}-3$ were eluted in volumes corresponding to dextrans of $\overline{\mathrm{MW}} 2 \times 10^{5} \sim 5 \times 10^{6}$. Although H-2 showed two peaks in this elution profile, sugar compositions of these two fractions were quite similar.

Fractionation of the crude pectin by DEAEcellulose column chromatography

Figure 4 shows the elution profile of the pectin of rice endosperm cell walls on DEAEcellulose (phosphate form). Table III shows the sugar composition of each fraction.

Fractions P-1, P-2 and P-3, which were eluted with $0.025,0.05$ and $0.1 \mathrm{M}$ sodium phosphate, respectively, showed different uronic acid contents $(0.8 \sim 35.1 \%)$ and gave arabinose and xylose in addition to less amounts of galactose,

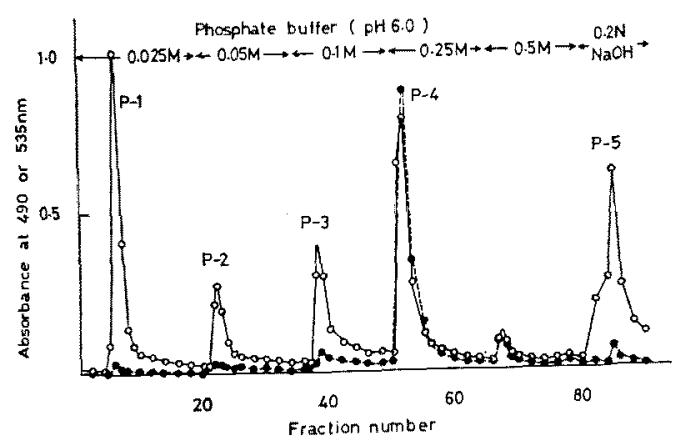

FIG. 4. DEAE-cellulose Column Chromatography of Pectin.

Pectin of the rice endosperm cell walls $(5 \mathrm{mg}$ in $5 \mathrm{ml}$ of $0.025 \mathrm{M}$ phosphate buffer, $\mathrm{pH} 6.0$ ) was applied to a column of DEAE-cellulose $(1.5 \times 40 \mathrm{~cm})$ which had been equilibrated with the same buffer. The eluate was collected in $10 \mathrm{ml}$ fractions and analyzed for both total carbohydrate and uronic acid. $0-0$, total carbohydrate;
TABLE III. Sugar Compositrons of Pectin Fractions

\begin{tabular}{lrrrrrr}
\hline \multirow{2}{*}{ Sugar } & \multicolumn{6}{c}{ Composition $(\%, w / w)$} \\
\cline { 2 - 7 } & \multicolumn{1}{c}{ P-1 } & \multicolumn{1}{c}{ P-2 } & \multicolumn{1}{c}{ P-3 } & P-4-I & P-4-II & P-5 \\
\hline Rham & 4.4 & 3.0 & 3.8 & 5.8 & 1.2 & 1.4 \\
Fuc & - & 0.9 & 0.5 & \multicolumn{1}{c}{ - } & - & - \\
Ara & 34.4 & 31.3 & 25.0 & 21.5 & 2.6 & 18.2 \\
Xyl & 27.5 & 31.3 & 21.2 & 7.3 & 1.5 & 39.3 \\
Man & 2.0 & 1.0 & 0.9 & - & 0.1 & 5.1 \\
Gal & 9.3 & 8.2 & 9.9 & 13.9 & 1.9 & 2.4 \\
Glu & 21.6 & 6.0 & 3.7 & 1.4 & 1.1 & 26.1 \\
Uronic acid & 0.8 & 18.6 & 35.1 & 49.5 & 90.8 & 10.1 \\
\hline
\end{tabular}

a Estimated in terms of galacturonic acid.

glucose and rhamnose upon acid hydrolysis. $\mathrm{P}-4$, which was eluted with $0.25 \mathrm{M}$ sodium phosphate, was the richest in uronic acid and further fractionated by gel filtration on a column of Sephadex G-50 (Fig. 5). The high molecular weight fraction, P-4-I, contained almost equal amounts of neutral and acidic sugars and gave arabinose, galactose, xylose and rhamnose as neutral sugar components upon acid hydrolysis. On the other hand, the low molecular weight fraction, P-4-II, contained over $90 \%$ of uronic acid.

The presence of galacturonic acid in the hydrolyzate of pectin was confirmed by paper chromatography with two solvent systems and also by gas chromatography as the trimethylsilylated methyl glycoside.

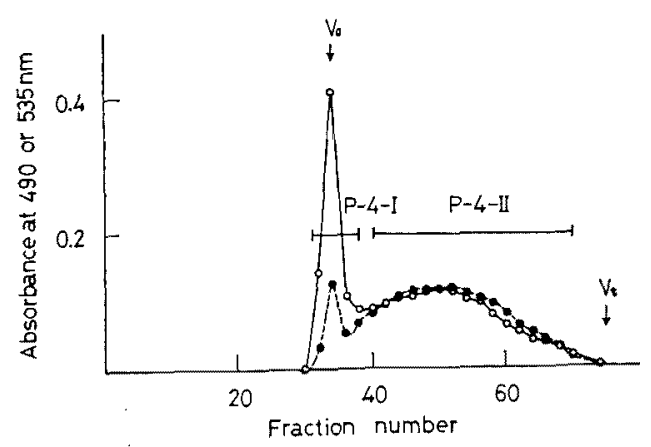

FIG. 5. Gel Filtration of P-4 on Sephadex G-50. P-4 (3 mg in $5 \mathrm{ml}$ of $0.1 \mathrm{M} \mathrm{NaCl}$ ) was applied to a column of Sephadex G-50 $(2.5 \times 90 \mathrm{~cm})$ which had been equilibrated with the same solution. The eluate was collected in $5 \mathrm{ml}$ fractions and analyzed for both total carbohydrate and uronic acid. $\mathrm{O}-\mathrm{O}$, total carbohydrate; -- uronic acid. 
Amino acid composition of the whole endosperm cell walls and $\alpha$-cellulose fraction

Table IV shows the protein contents and amino acid compositions of whole endosperm cell walls and $\alpha$-cellulose fraction. The amino acid composition of the major reserve protein of rice, glutelin, ${ }^{24}$ is also cited for reference. The protein content of the whole wall preparation was ca. $3 \%$, and its amino acid composition was quite different from that of glutelin. Especially, the hydroxyproline content of the cell wall was much higher than that of glutelin. In the $\alpha$-cellulose fraction, which contained ca. $1 \%$ protein, the proportion of hydroxyproline reached $30 \%$. On the contrary, this fraction contained but a small amount of glutamic and aspartic acids, which were richly contained in glutelin.

TABle IV. AmINo Acid Compositions of Whole Cell Wall Preparation and $\alpha$-Cellulose Fraction

\begin{tabular}{lccc} 
& \multicolumn{3}{c}{ Amino acid composition $(\mathrm{mol} \%)$} \\
\cline { 2 - 4 } & Whole wall & $\alpha$-Cellulose & Glutelin $^{a}$ \\
\hline Arg & $4.6(4.3)^{b}$ & 2.5 & 7.4 \\
His & $1.8(1.4)$ & 0.8 & 2.3 \\
Lys & $2.2(1.9)$ & 1.1 & 3.2 \\
Phe & $4.1(5.6)$ & 6.1 & 4.7 \\
Tyr & $2.6(3.1)$ & 2.7 & 3.9 \\
Leu & $7.3(9.1)$ & 9.9 & 7.7 \\
Ileu & $3.2(4.4)$ & 4.1 & 4.9 \\
Met & $1.2(0.8)$ & 0.7 & 1.0 \\
Val & $5.7(6.4)$ & 5.7 & 7.6 \\
Ala & $8.2(9.2)$ & 10.3 & 7.2 \\
Gly & $8.2(6.9)$ & 6.5 & 7.6 \\
Pro & $4.4(3.4)$ & 2.5 & 4.9 \\
Glu & $11.9(9.3)$ & 4.9 & 16.8 \\
Ser & $5.3(5.0)$ & 3.8 & 7.1 \\
Thr & $3.4(3.5)$ & 3.4 & 3.8 \\
Asp & $6.6(6.7)$ & 4.6 & 10.3 \\
Hypro & $19.2(19.2)$ & 30.3 & - \\
\hline
\end{tabular}

a Data of Sawai et al. ${ }^{24}$ ?

b Calculated values based on the assumption that the protein of the whole wall preparation is composed of the hydroxyproline-containing protein for $63.4 \%$ found in the $\alpha$-cellulose fraction and of glutelin for $36.6 \%$.

\section{DISCUSSION}

In the endosperm of rice kernels, starch granules, insoluble protein and endosperm cell walls are firmly bound to each other and form a hard and glassy endosperm structure. The attempts to isolate the endosperm cell walls by mechanical methods such as sonication and centrifugation were unsuccessful for this reason. The isolation procedure reported here included the degradation of starch by gelatinization and simultaneous amylase digestion. Although the time required for this treatment was not so long $\left(30 \mathrm{~min}\right.$, at $\left.93^{\circ} \mathrm{C}\right)$, a part of cell wall components was suspected to be solubilized during this process. To clarify this point, non-starchy polysaccharide (WS), which was extracted during this process, was recovered and analyzed. Since the yield of WS was low, ca. $20 \%$ of that of cell wall preparation, and also since a part of this fraction might have been originally soluble, it seemed that the loss of cell wall components during this process was small and the cell wall preparation so obtained well reflected the chemical properties of the native cell walls.

Rice endosperm hemicellulose, which constituted over $40 \%$ of the total cell wall components, mainly comprised arabinoxylans having a high arabinose: xylose ratio. A large portion of the arabinoxylans contained uronic acid in their structures. A glucose-containing polysaccharide, which showed a starch-like color reaction with iodine, was also found in the hemicellulose fraction. The latter polysaccharide, however, should not be the starch remnant, since it could not be further degraded by the amylases. The detailed structural features of this polysaccharide will be reported in a subsequent paper. $^{25}$ ) The finding that the main hemicellulosic components of the rice endosperm cell walls are arabinoxylans well agrees with the results previously obtained by other authors. ${ }^{11 \sim 13)}$ It has been reported that hemicellulose of wheat endosperm is also composed of arabinoxylan..$^{10,14}$, On the other hand, Fincher ${ }^{15)}$ reported that the main hemicellulosic component of barley endosperm cell walls were $\beta$-glucan. These facts suggest possible differences among cereal species.

The presence of pectic substances which were 
commonly found in primary cell walls has not been confirmed in the endosperm cell walls of wheat $^{14\rangle}$ and barley. ${ }^{15\rangle}$ In the case of rice, however, there were several fractions (P-4-I and P-4-II) which contained the component sugars characteristic of pectic substances, such as galacturonic acid, rhamnose and galactose. Moreover, the fact that the neutral sugar-rich fraction (P-4-I; uronic acid content, $51 \%$ ) contains arabinose, galactose, xylose and rhamnose as neutral sugar components well agrees with the hypothesis ${ }^{26,27}$ ) that arabinogalactan or xylose-containing side chains are linked to the back bone chain of rhamnogalacturonan in the pectic substances of primary cell walls. Although the molecular weight of P-4-II seems to be fairly light (less than 10,000), it is not certain if it was caused by the partial depolymerization of the pectic polymers during the purification process.

The presence of hydroxyproline-containing glycoprotein in the primary cell walls of many types of plant species has been reported, ${ }^{28,29}$ ? but it has not been confirmed in the endosperm and aleulon cell walls of cereal grains. ${ }^{14,15,30 \text {; }}$ The results of the amino acid analysis of the rice endosperm cell walls and $\alpha$-cellulose fraction suggest that glycoprotein of this type is present in these cell walls and firmly bound to cellulose microfibrils. The hydroxyprolinecontaining protein in the $\alpha$-cellulose fraction seems to retain its original structure in spite of extraction with strong alkali, because the calculated values of amino acid composition show satisfactory agreement with the experimental ones, the calculation being based on the assumption that the proteins of the whole wall preparation are the mixture of glutelin and the hydroxyproline-containing wall protein (Table IV, in parentheses). Heath et al. ${ }^{31}$, also reported the association of the hydroxyproline-containing glycoprotein with the $\alpha$ cellulose fraction of the cultured sycamore cell walls.

Acknowledgement. We wish to thank Prof. A. Misaki of Osaka City University and Prof. S. Wada of Tohoku University for their helpful advices. We are grateful to Dr. S. Chikubu for his encouragement throughout this work. We are also indebted to Mr. T. Suzuki for amino acid analysis and Nissei Sangyo Co. for scanning electron microscopic observation.

\section{REFERENCES}

1) M. J. Wolf, H. L. Seckinger, E. C. Rosewall, M. M. MacMasters and C. E. Rist, Cereal Chem., 29, 399 (1952).

2) R. A. Larkin, M. M. MacMaster and C. E. Rist, ibid., 29, 407 (1952).

3) K. Kulp and W. G. Bechtel, ibid., 40, 493 (1963).

4) W. T. Yamazaki, ibid., 32, 26 (1955).

5) H. S. R. Desikachar and V. Subramanyan, ibid., 36, 385 (1959).

6) N. Sugano, K. Kaya, H. Akiyama and K. Nojiro, J. Soc. Brew. Japan, 66, 705 (1971).

7) L. Taiz and R. L. Jones, Planta, 92, 73 (1970).

8) R. G. Fulcher, T. P. O'Brien and J. W. Lee, Aust. J. Biol, Sci., 25, 23 (1972).

9) G. O. Aspinall and C. T. Greenwood, J. Inst. Brew., 68, 167 (1962).

10) B. L. D'appolonia, K. A. Gilles, E. M. Osman and Y. Pomeranz, "Wheat, Chemistry and Technology," ed. by Y. Pomeranz, Am. Assoc. Cereal Chemists Inc., St. Paul, Minn., 1971, p. 352.

11) Y. Matsuo and A. Nanba, Hakko Kogaku Zasshi, 36, 190 (1958).

12) A Bevenue and K. T. Williams, J. Agric. Food Chem., 4, 1014 (1956).

13) A. V. Cartano and B. O. Juliano, ibid., 18, 40 (1970).

14) D. J. Mares and B. A. Stone, Aust. J. Biol. Sci., 26, 793 (1973)

15) G. B. Fincher, J. Inst. Brew., 81, 116 (1975).

16) N. Sugano, H. Akiyama and K. Nojiro, Nippon Nôgeikagaku Kaishi, 47, 763 (1973).

17) A. Kivilaan, T. Beaman and R. S. Bandurski, Nature, 184, B. A. 81 (1959).

18) M. Dubois, K. A. Gilles, J. K. Hamilton, P. A. Rebers and F. Smith, Anal. Chem., 28, 350 (1956).

19) E. A. McComb and R. M. McCready, ibid., 24, 1630 (1952).

20) J. F. Saeman, W. E. Moore and M. A. Millet, "Methods in Carbohydrate Chemistry," Vol. III, ed. by R. L. Whistler, Academic Press Inc., New York, N. Y., 1963, p. 54

21) J.S. Sawardeker, J. H. Sloneker and A. Jeanes, Anal. Chem., 37, 1602 (1965).

22) C. C. Sweely, R. Bently, M. Makita and W. W. Wells, J. Am. Chem. Soc, 85, 2497 (1963).

23) O. H. Lowry, N. J. Rosebrough, A. L. Farr and R. H. Randall, J. Biol. Chem., 193, 265 (1951).

24) H. Sawai, H. Nikaido and Y. Morita, Agric. Biol. Chem., 34, 1039 (1970).

25) N. Shibuya and A. Misaki, ibid., 42, 2267 (1978).

26) G. O. Aspinall, "The Carbohydrates," Vol. IIB, 
ed. by W. Pigman and D. Horton, Academic Press Inc., New York, N. Y., 1970, p. 515.

27) K. T. Talmadge, K. Keegstra, W. D. Bauer and P. Albersheim, Plant Physiol., 51, 158 (1973).

28) D. T. A. Lamport, Adv. Bot. Res., 2, 151 (1965).

29) D. T. A. Lampott and D. H. Miller, Plant Physiol.
48, 454 (1971).

30) M. McNeil, P. Albersheim, L. Taiz and R. L. Jones, ibid., 55, 64 (1975).

31) M. F. Heath and D. H. Northcote, Biochem. J., 125, 953 (1971). 